\title{
A mobile application for biliary atresia screening
}

\section{Uso de una aplicación médica en el teléfono celular para la detección de atresia de vías biliares}

Miguel Á. González-Cruz ${ }^{1}$ and Alejandro Ferreiro-Marín ${ }^{2}$

${ }^{1}$ Departamento de Pediatría; 'Departamento de Gastroenterología. Centro Médico ABC Campus Santa Fe, Mexico City, Mexico

In the article Colorimetric card use for early detection of visual biliary atresia, the impact of the incorporation of a visual colorimetric card in the Cartilla Nacional de Salud (National Health Card) (since 2013) in two third level of care pediatric hospitals from the Instituto Mexicano del Seguro Social, Mexico City, was analyzed. Patients were recruited from January 2010 to June 2015. In this study, it was concluded that the intervention did not decrease the age of referral, the age at diagnosis, or the age at surgery in patients with biliary atresia ${ }^{1}$.

In other countries, such as Taiwan and Japan, this screening program has been successfully implemented. This result relies on several factors, such as the adequate training of the parents on the use and identification of feces by the visual colorimetric card, available telephone communication 24 hours a day in cases of suspicion, close monitoring of each case until the establishment of a definitive diagnosis, and the wide coverage of the visual colorimetric card among the population ${ }^{1,2}$.

The adequate identification of abnormal stools represents a challenge both for parents and health professionals. Some reports showed that pediatricians and nurses could not detect acholic feces in up to $37.2 \%$ of cases $^{3}$. An option to encounter this difficulty is the use of a cell phone medical application for the detection of acholic feces, such as PoopMD or Baby Poop, which work through the smartphone camera and use software to perform a color recognition analysis, with reports of
$100 \%$ sensitivity and $89 \%$ specificity ${ }^{4,5}$. These medical applications offer certain advantages over traditional visual colorimetric cards, such as the option of receiving weekly reminders during the critical period of the first 90 days of life, as well as the option of automatically notifying the primary care physician by email or directly in case of detecting an acholic evacuation, which could shorten the time of referral, diagnosis and surgical treatment in these patients ${ }^{1,4}$.

The main disadvantages of these medical applications are that they cannot be used with all smartphones, require expensive or new generation devices, there are no Spanish versions and, despite the optimism that comes with these applications, it is necessary to conduct more experimental studies to demonstrate their usefulness for screening biliary atresia.

\section{References}

1. Reyes-Cerecedo A, Flores-Calderón J, Villasis-KeeverM, Chávez-BarrerraJ, Delgado-González E. Uso de la tarjeta colorimétrica visual para la detección oportuna de atresia de vías biliares. Bol Med Hosp Infant Mex. 2018;75:160-5.

2. Chen S, Chang M, Du J, Lin C, Chen A, Lee HC, et al. Screening for biliary atresia by infant stool color card in Taiwan. Pediatrics. 2006; 117:1147-54.

3. Bakshi B, Sutcliffe A, Akindolie M, Vadamalayan B, John S, Arkley C, et al. How reliably can paediatric professionals identify pale stool from cholestatic newborns? Arch Dis Child Fetal Neonatal Ed. 2012;97:F385-7.

4. Franciscovich A, Vaidya D, Doyle J, Bolinger J, Capdevila M, Rice M et al. PoopMD, a mobile health application, accurately identifies infant acholic stools. PLOS ONE. 2015;10:e0132270.

5. Hoshino E, Hayashi K, Suzuki M, Obatake M, Urayama KY, Nakano S, et al. An iPhone application using a novel stool color detection algorithm for biliary atresia screening. Pediatr Surg Int. 2017;33:1115-21.
Available online: $30-10-2019$
Bol Med Hosp Infant Mex. 2019;76:50

www.bmhim.com 